Article

\title{
Improving the Healthiness of Sustainable Construction: Example of Polyvinyl Chloride (PVC)
}

\author{
Emina Kristina Petrović * and Lydia K. Hamer \\ School of Architecture, Victoria University of Wellington, P.O. Box 600, Wellington 6140, New Zealand; \\ lydiakhamer@gmail.com \\ * Correspondence: Emina.Petrovic@vuw.ac.nz; Tel.: +64-4-463-5518
}

Received: 23 December 2017; Accepted: 5 February 2018; Published: 7 February 2018

\begin{abstract}
With the increasing emphasis on sustainable construction, it has become important to better understand the impacts of common materials. This is especially paramount with the introduction of the United Nations (UN) Sustainable Development Goals (SDGs) which call for more comprehensive evaluations, adding many aspects of social consideration to the issues of environmental sustainability, including human health. Polyvinyl chloride (PVC)/vinyl can be seen as a material with potential for significant adverse effects on a multiplicity of levels, and the construction industry is its single most significant consumer. This article presents a transdisciplinary review of adverse health impacts associated with PVC showing a number of issues: some that could be eliminated through design, but also some which appear inherent to the material itself and therefore unavoidable. The totality of issues revealed in relation to PVC presents a compelling case for a call for complete elimination of use of this material in sustainable construction.
\end{abstract}

Keywords: polyvinyl chloride; PVC; vinyl; phthalates; recycled PVC; human health; toxicity of building materials; sustainable construction; Sustainable Development Goals (SDGs)

\section{Introduction}

Greenpeace has been campaigning for a global ban of polyvinyl chloride (PVC)/vinyl manufacture for the last thirty years [1]. Despite these efforts, in 2016, world consumption of PVC was around 40 million tons, and this is still expected to rise by $2.3 \%$ per year until 2024 [2]. Globally, PVC is the third largest commodity plastic [3]. This article focuses on PVC in the construction industry, because currently such products are the single most significant user of PVC, representing as much as about $60-70 \%$ of its total consumption [2,4]. In the construction industry, PVC is used in applications such as pipes, wiring, films, profiles, sheets, fastening elements, flooring, wallpaper, and coatings. Therefore, any significant changes in construction applications could have a direct impact on global production and consumption of this material.

This article proposes that an increased awareness and education on the issues associated with PVC could support decrease in its use in the construction industry. Earlier work has suggested that amongst architects there is already a wide-spread understanding that PVC is problematic [5]. Similarly, a number of green schemes by now recognize that at least phthalate plasticizers can pose problems in PVC. However, the article presents a more detailed insight into the complexity of health issues associated with PVC, which can be used as a basis for more informed decisions by built environment practitioners.

It is especially important to consider materials such as PVC in more detail because of an increasing understanding of the importance of the Sustainable Development Goals (SDGs), accepted by the United Nations in 2015, as an aspirational set of 17 goals until 2030 [6]. The SDGs set up a comprehensive system asking for environmental sustainability to be expanded to include many aspects of sustainability found in society and social relations, strongly asserting a high level of interrelatedness between the 
goals. Within this context, specific aspects in one area of human activities, such as the construction industry, can prove to have significant impacts in a number of other areas. For construction and built environment disciplines, building materials present one important facilitator of such interconnections.

Figure 1 shows a theoretical consideration of a series of cascading relationships between the SDGs triggered by the evaluation of building materials in terms of their impact on human health. It shows a progression from the more obviously relevant top level goals to two subsets of intermediate level goals triggered by the top level goals, and finally to the abstract level goals. SDG3-Good health and well-being goal is related to SDG15-Life on land, SDG14-Life below water, and SDG6-Clean water and sanitation, while SDG11-Sustainable cities and communities is related to SDG12-Responsible consumption and production, SDG9-Industry, innovation and infrastructure, SDG10-Reduced inequalities, and SDG8-Decent work and economic growth. From these intermediate level goals, it is further possible to observe the more abstract level goals triggered by the consideration of healthiness of building materials: SDG13-Climate action and SDG17-Partnership for the goals. Therefore, by using the SDGs framework, a consideration of the building materials in relation to human health can lead to a much broader consideration of 11 out of 17 SDGs, and contribute to improvements in areas which are not commonly assumed to be part of concerns of construction and built environment industries, such as quality of life below water or reductions in social and work inequalities.

TOP LEVEL

obviously relevant SDGs

\section{INTERMEDIATE LEVEL}

less obvious, clear through the lenses of top level SDGs

ABSTRACT LEVEL relevant through the totality of observed implications

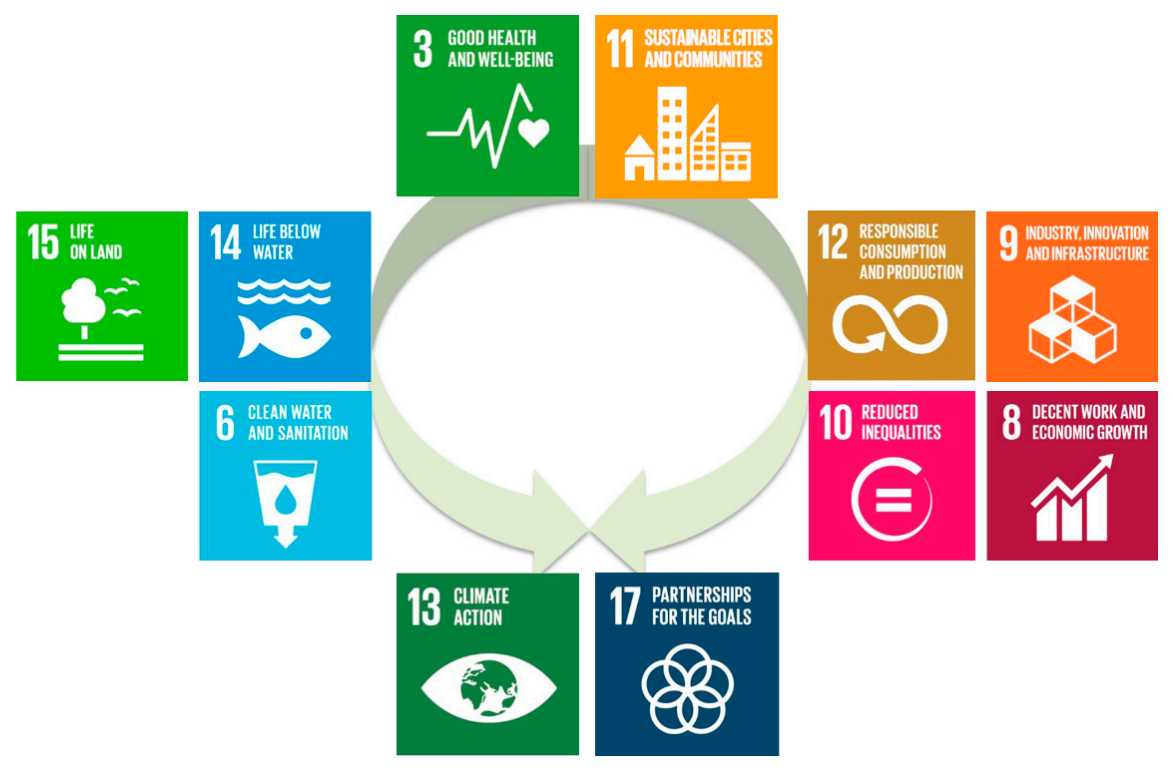

Figure 1. Diagram of relevant Sustainable Development Goals (SDGs) for assessing healthiness of building materials (Diagram: Emina Kristina Petrović.).

Although there are mixed findings on how effective the impact of knowledge is on direct pro-sustainable change of behavior of individuals $[7,8]$, when considering the societal transitions and transformations towards sustainability recent scholarship has proposed approaches such as the transition dynamics framework [9,10]. Transition dynamics framework uses six transition phases, with the middle two (shared understanding and issue agreement; and knowledge dissemination) signaling the importance of shared knowledge as prerequisites for actual change [9,10]. Reflecting this stage, the construction industry is currently placing a high emphasis on voluntary regulations, which additionally increases the importance of good understanding of the issues.

Therefore, both from the position of SDGs and the transition dynamic framework, an increase in general understanding of the complex issues presented by PVC could help with reductions of its use in sustainable construction. 


\section{Background-PVC within the Context of Other Polymers and Synthetic Chemicals}

PVC belongs to a broader group of polymers or plastics nowadays in everyday use. Since the second half of the 19th century, and especially since World War Two, a large number of new human-made, synthetic chemicals have been developed, and this is still an accelerating trend [11,12]. Reflecting upon such innovation, many of the common plastics were developed between the mid-1920s and immediate post World War Two. PVC, polyethylene (PE), poly(ethylene terephthalate) (PET), polystyrene, poly(styrene-butadiene) (SBR), ply(styrene-co-acrylonitrile) (SAN), poly(acrylonitrile-co-butadiene-co-styrene) (ABS), polycarbonate, polyurethane (PU), nylons, aramids and polyamides were all invented and entered manufacture during this period [13].

Currently, as much as $95 \%$ of all synthetic substances are manufactured from fossil resources [14]. The majority of plastics are produced using seven key hydrocarbons (compounds consisting entirely of hydrogen and carbon) as their building blocks (ethylene (C2), propylene (C3), C4 olefins or butadiene (C4), benzene (C6), toluene (C7), and xylene (C8)) [13]. The majority of these chemicals are generated by breaking up higher carbon chemicals (molecules with greater numbers of carbon atoms) found in fossil fuels into lower carbon chemicals (molecules with fewer carbon atoms). Steam cracking of crude oil and natural gas is a commonly used process to achieve this breaking. It is an energy intensive process which produces residues which vary from being harmless to highly toxic [15-17]. Although the hydrocarbons vary on many levels, they all pose significant risks for human and environmental health, they are also all flammable, some require pressurized storage, and many are volatile organic compounds (VOCs) [13]. Of all hydrocarbons, ingredients for the most common plastics are in highest demand. For example, in recent years, polyethylene (PE) has been the plastic in highest demand globally which would have made its hydrocarbon, ethylene, globally very desirable.

Although development of synthetic chemicals stimulated positive improvements and the modernization of many everyday aspects of life it also brought some new problems. By the 1960s and 1970s concerns began to be raised about many of these new chemicals. In 1962, Rachel Carson criticized overuse of DDT and generally proposed that the increase in use of synthetic chemicals had potential to devastate environmental health [18]. Adding to this, in 1984, the United States (US) National Academy of Science/National Research Council reported that the majority of the US High Production Volume (HPV) chemicals had no data on their toxicity, with minimal data available for only $22 \%$ of HPV chemicals [11]. The HPV chemicals are the most commonly used chemicals, nowadays defined as those used in amounts higher than 1 million tons per year. Worldwide, there are about 30,000 substances in the group of HPV chemicals. Although improvements in this area have been constant, by the end of the 20th century it was estimated that in the EU only about $14 \%$ of HPV chemicals had the most basic data publicly available and for $21 \%$ no data existed at all; in the US only $7 \%$ of HPV chemicals had full toxicity data and no information on toxicity was available for $43 \%[11,19]$. Therefore, many assessments of impact of synthetic chemicals operate within this context of limited understanding of how problematic many of these chemicals are, and this is still the case for PVC.

PVC was discovered in 1872, but its potential applications were not recognized for more than 50 years because without additives PVC is a white powdery dust [20]. Nowadays, PVC comes in two broad types of material: plasticized and unplasticized PVC. Plasticized PVC (pPVC) is flexible and is used in applications that require flexibility (such as flooring, wiring and wallpaper). Unplasticized PVC (uPVC) is rigid and is used for applications that do not require flexibility (such as pipes and cladding). The main difference between the PPVC and UPVC is in additives, which influence the material properties and recyclability. Vinyl flooring was one of the common products using pPVC. In 1933, vinyl flooring was displayed at the Century of Progress Exposition in Chicago, although it did not become commercially available until the end of World War Two. In the early decades of peace, vinyl became a fashionable material not only for flooring, but also for vehicle seat covers, vinyl clothing, and vinyl records. In the decades that followed, vinyl flooring largely overtook the use of its older and natural alternative: linoleum, resulting in linoleum manufacture almost disappearing. 
PVC is produced through polymerization of vinyl chloride monomer (VCM) or vinyl chloride [20]. Therefore, in order to fully understand the health impacts from the PVC, it is essential to understand the impacts of its components.

\section{Health Issues with the Core Elements of VCM: Ethylene and Chlorine}

VCM is produced from ethylene and chlorine (Figure 2). Ethylene (or ethene) can be seen as one of the less dangerous hydrocarbons because it appears in nature as a natural plant hormone. It is a colorless gas with a sweet odor and taste, lighter than air, extremely flammable, therefore requiring pressurized storage. The European Chemicals Agency (ECHA) and the US National Center for Biotechnology Information (PubChem) report that it may cause drowsiness or dizziness, it is known for specific organ toxicity from single exposure, it is harmful to aquatic life with long-lasting effects and, because of this, it should not be released into the environment [21,22]. It is classified by the International Agency for Research on Cancer (IARC) as a class 3 carcinogen, which means that there is inadequate evidence that it is carcinogenic. Although it compares favorably with other hydrocarbons, clearly extensive use of ethylene can present human and environmental health problems. Despite this in 2013, more than 130 million metrics tons of ethylene were manufactured [2].

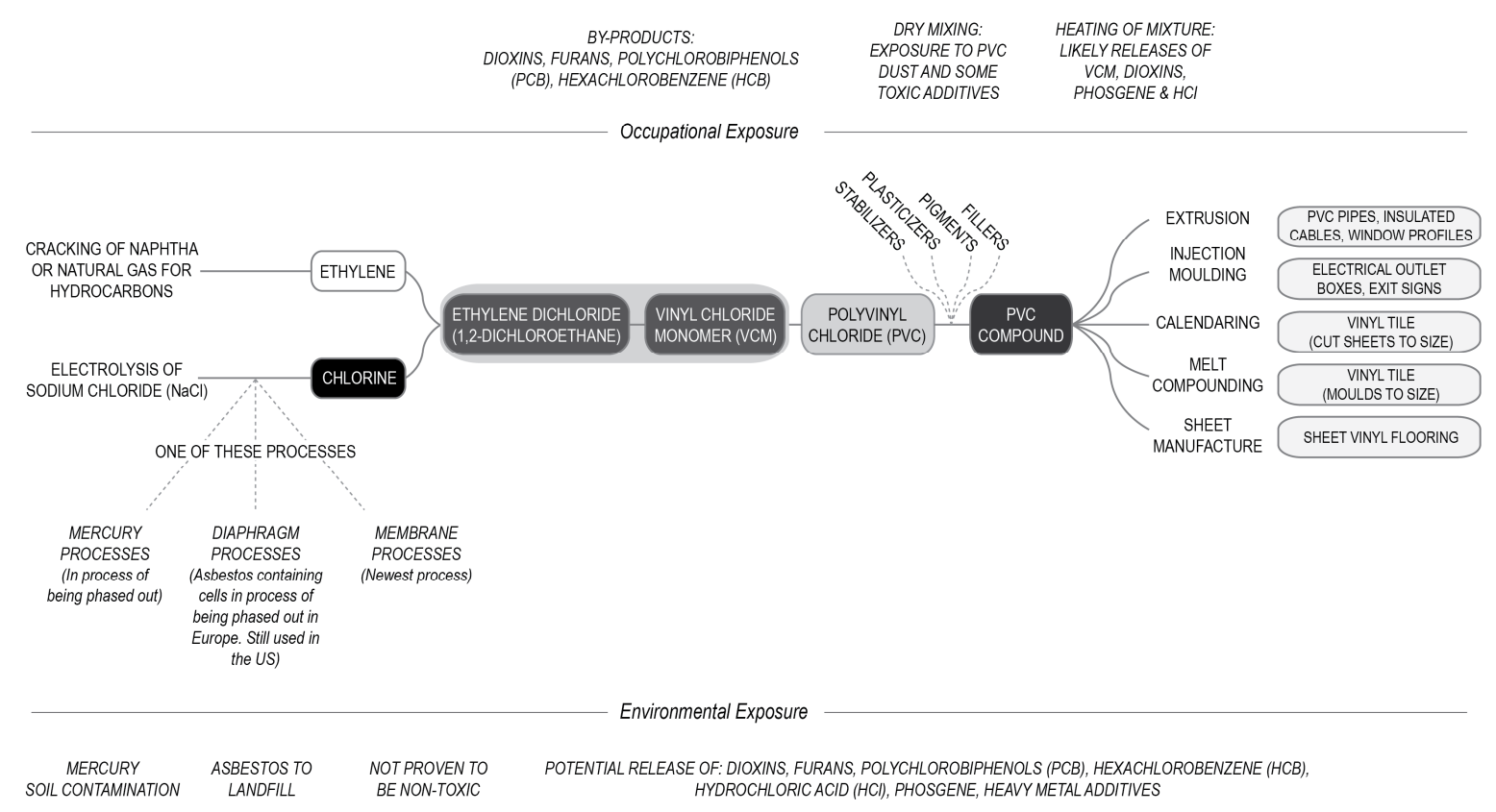

Figure 2. Diagram summarizing the most common manufacture of polyvinyl chloride (PVC) process showing the likely health issues in different stages. (Diagram: Lydia Hamer and Emina Kristina Petrović.)

Theoretically, PVC could be synthesized without the use of petrochemicals. However, currently its production relies on the use of ethylene obtained from the petrochemical industry and, because of this, manufacture of its intermediates and the final PVC product are often located within petrochemical complexes [23]. (This process is described in Figure 2.) Therefore, contemporary PVC should be seen as part of a broader range of petrochemicals. Furthermore, manufacture of PVC currently competes for ethylene with the manufacture of polyethylene (PE), while PE is considered to be one of the safer polymers used in contemporary manufacture [13].

Issues associated with chlorine are more extensive. Chlorine $(\mathrm{Cl})$ is one of the natural elements which, because of its high reactivity, in nature only appears reacted. In elemental form, chlorine is 'a greenish yellow gas with a pungent suffocating odor', which is toxic by inhalation [21]. The best known natural compound containing chlorine is the sodium chloride $(\mathrm{NaCl})$, or table salt. Because of its reactivity, methods to synthetically extract or synthetize chlorine have only been developed during 
the 19th century, and elemental chlorine itself requires special manufacture from other components. Of all industrial uses, currently, PVC manufacture is the most significant consumer chlorine with about $30 \%$ of elemental chlorine used in PVC [1,24].

There is more than one way to produce chlorine for industrial use. One of the processes uses the electrolysis of sodium chloride [25]. The sodium chloride is dissolved in water to create a brine, which is then electrolyzed. Electrolysis occurs in separate electrolytic cells. Chlorine gas is released at the anion, and hydrogen gas and sodium hydroxide $(\mathrm{NaOH})$ are released at the cation. While this appears to be a simple enough process, the challenge is to prevent the mixing of these products. Contemporary industry uses a variety of processes to separate the cathode and anode, and their products [25]. These include the diaphragm processes, mercury processes and membrane processes (Figure 2).

The membrane cell has the lowest power consumption of the three technologies [25]. The membrane cell comprises of two cells (the anode and the cathode), separated by a bilayer perfluorinated membrane. Brine is channeled into the anodic compartment, where chlorine gas is produced. The sodium passes through the membrane into the cathode compartment where hydrogen gas and sodium hydroxide are produced. Almost all new chlor-alkali plants being built are of the membrane process as it is considered best practice [25], despite relative absence of studies of its safety.

However, older approaches which are still in use in many places presented very significant problems. One older approach uses the mercury cell process in which mercury acts as the cathode and produces an amalgam with sodium, allowing for the release of chlorine at the anode [25]. Unsurprisingly, the mercury process presents some hazards due to the potential for occupational exposure to mercury and mercury vapors, which are neurotoxins. Mercury $(\mathrm{Hg})$ is a toxic heavy metal, hazardous to fetal and intelligence quotient (IQ) development. It causes health problems from acute exposure to high levels, or chronic exposure to low doses [26]. Former mercury process sites show signs of soil contamination [25]. This was the most common technology, but its use declined in the later part of the 20th century [27]. As of 2011 the mercury process capacity has been below $10 \%$ of the international production capacity; the mercury cell is no longer produced or installed and there is a voluntary commitment by European manufacturers to phase out the use of the mercury cell process by 2020 [25].

Following a reduction in use of the mercury cell process, the diaphragm-cell process became the primary cell technology for producing chlorine and caustic soda. Up until the 21st century asbestos was a primary component of the diaphragm cell [27]. A closely woven steel screen covered with long fiber (chrysotile) asbestos and barium sulfate was used to separate the cells [27]. Despite asbestos being largely banned in most developed countries some diaphragms with asbestos are still in use. In the European Union (EU) the technology is still used due to a derogation which allows chrysotile diaphragms, which were in use on 13 July 2016, to remain in use until 2025 subject to certain conditions set out in Directive 2010/75/EU [28]. Similarly, as of 2017, this industrial application is the only user of raw asbestos in the US. The standard diaphragm cell lasts approximately 1-3 years, and after that the asbestos is pulled out and sealed into containers and sent to landfills which accept asbestos [29]. It seems reasonable to assume such procedures will be undertaken with asbestos which is currently still in use.

Therefore, some of these processes present significant occupational and environmental health concerns associated with the industrial manufacture of chlorine. Unfortunately, even if those were to be completely eliminated, the problems with chlorine do not end there.

Chlorine is a strong oxidant, which means that it readily reacts with organic molecules to produce a variety of chlorinated compounds. It is nowadays used in a number of industrial process raging from bleaching agents, solvents, flame retardants, pigments, to intermediates of other synthetic processes and chlorination of drinking water [21]. In drinking water chlorine can react with dissolved organic matter creating a number of potentially harmful disinfection by-products $[30,31]$. 
Although some of the chloride containing chemicals are essential to life, such as sodium chloride, unfortunately a number of issues have also been observed with many of synthetically generated organochloride chemicals. For example, all of the 12 initially listed persistent organic pollutants (POPs) to be eliminated under the Stockholm Convention are organochloride chemicals, mainly used as insecticides and fungicides [32]. One important subgroup on the list of persistent organic pollutants are dioxins. Dioxins are a group of highly toxic, environmentally persistent compounds which are found throughout the environment and accumulate in the food chain [33]. They are unintentionally produced, often due to incomplete combustion or during certain manufacturing processes. All chlorine containing materials when incompletely combusted in presence of organic material can lead to the formation of dioxins [3].

In plastics, a number of chlorinated polymers have been developed often with excellent performance properties, such as chlorinated polyethylene (CPE), chlorinated polyvinylchloride (CPVC) and chlorosulfonated polyethylene (CSPE), which have all been introduced into the construction industry [34]. However, chlorinated polymers can contain volatile components which can be released while in use and it is increasingly known that use of such products can lead to potential for release of dioxins [34]. Consequently, there has been a reduction in manufacture of many such materials. The exception to this trend is the use of chlorine in PVC.

Therefore, the key components for manufacture of PVC can be seen as problematic for human and environmental health and well-recognized as risks. While this is only somewhat the case for ethylene, it is very clearly the case for chlorine. Manufacture of PVC is competing with the manufacture of PE, which is a reasonably safe plastic, for ethylene; PVC also consumes about one third of all chlorine in industrial use, together with all problems associated with the industrial production and use of chlorine. As explained, the use of ethylene can be designed out and avoided, while the use of chlorine is inherent and unavoidable for this material. It is possible that manufacture of chlorine will over time develop better approaches, however, the health issues related to chlorine itself will remain.

\section{VCM Production}

The next essential component in manufacture of PVC is VCM, and it is impossible to manufacture PVC without the use of VCM. Although there is more than one way to generate VCM, this is where ethylene and chlorine react with each other. VCM is a colorless gas with a mild, sweet odor. It is extremely flammable, it self-ignites on higher temperatures, and may release toxic fumes when heated [21]. There are serious concerns about the health effect of VCM which are discussed in more detail in the next section.

The manufacture of VCM from ethylene and chlorine can be done in a single stage, or by producing the intermediate product of ethylene dichloride (1,2-dichloroethane) which is then heated to produce VCM. The ethylene dichloride process is described in Figure 2. Ethylene dichloride is produced by reacting ethylene and chlorine together in processes called chlorination and/or oxychlorination. The integration of the two processes ensures that more ethylene dichloride is made from the raw products and less product is lost in the process [35].

First ethylene and chlorine are reacted together in a chlorination reactor, which uses ferric chloride-based catalysts $\left(\mathrm{FeCl}_{3}\right)$ [36]. This produces ethylene dichloride. The ethylene dichloride is then 'cracked' under high heat in a furnace to produce VCM, and the by-product hydrochloric acid or hydrogen chloride $(\mathrm{HCl})$, which can be cycled back into the system for reuse in the oxychlorination unit. The oxychlorination process reacts ethylene with hydrochloric acid to produce further ethylene dichloride, which is then thermally cracked to produce VCM. The oxychlorination process relies on $\mathrm{CuCl}_{2}$-based catalysts [36,37].

Following thermal cracking, to stop VCM from decomposing further it is cooled through a process called quenching. VCM is cycled through long tubes which act as heat exchanges. The VCM is then purified in distillation columns, before being stored [35]. Although the integration of the chlorination and oxychlorination processes maximize use of the products, some highly toxic waste is produced in 
the process. For every ton of ethylene dichloride an approximate four kilograms of by-products are produced, which contain persistent toxic chemicals. This includes several organochloride chemicals which are recognized persistent organic pollutants (POPs): dioxins, furans, polychlorobiphenols (PCB), hexachlorobenzene (HCB) [32,38]. Multiple studies which looking into oxychlorination have found that extensive formation of carbon oxides takes place, as well as the formation of 1,1,2-trichloroethane [36], chloral (trichloroacetaldehyde), cis and trans-1,2 dichloroethylenes, mono-, di- tri- and tetrachloromethanes. 1,1,2 trichloroethane was also a by-product of the chlorination reactor [39].

One of the obvious problems with this manufacture process is its use of ethylene dichloride which presents a range of health risks. Ethylene dichloride is a colorless, oily, synthetic chemical, with a pleasant smell similar to chloroform, which releases toxic hydrochloric acid when heated [21]. It is a highly flammable liquid and vapor and under the European Registration, Evaluation, and Assessment of Chemicals (REACH) it has to be identified as a substance which may be fatal if swallowed and entering airways and is toxic if inhaled [22]. It is currently classified as a Group B2, probable human carcinogen, although some studies already suggest that it is reasonable to anticipate that it is a human carcinogen [21]. Acute exposure to ethylene dichloride can lead to toxic reactions in a number of organs and systems of organs, while there is to date insufficient information on the chronic exposure with some suggestions that it leads to changes to the liver and kidneys and impacts on the immune system and central nervous system [21]. Currently, around 1-10 million metric tons of ethylene dichloride are used per year in the European Economic Area alone [22].

However, ethylene dichloride is not unavoidable in manufacture of VCM. Prior to 1965 new VCM plants still used the 'single addition' process. In this process VCM is produced from acetylene and hydrogen chloride in one step, often using coal as a catalyst. Acetylene is produced from calcium carbide, which is itself a coal product [40]. The disadvantages of this process are the number of by products produced and the greater cost of acetylene, in comparison to ethylene. However, this method requires less capital investment and can be carried out on a much smaller scale, which made it a common production method in countries who are at an early stage in their PVC industry [41]. China is now the sole country to operate acetylene-based plants [42]. China is the largest consumer and producer of VCM. In 2016 it had $43 \%$ of the total global capacity, 38\% of the total global production and China's consumption accounts for $40 \%$ of global demand [43]. More than half of China's VCM production capacity is based on the carbide process [26]. In this process acetylene is reacted with hydrochloric acid $(\mathrm{HCl})$ through the use of a mercury containing catalyst [40]. The largest industrial user of mercury in China, is the VCM industry. Recent work has indicated that pollution from the intentional use of mercury in industrial processes includes a number of known pathways (landfill, waste incineration, breakage in use and recycling) and some unknown pathways [26]. In 2011, about 200 tonnes of mercury from industrial processes in China had unknown fates [26].

Therefore, currently common VCM manufacture processes involve highly hazardous components.

\section{Health Impacts from VCM in the PVC Industry}

VCM is a known human carcinogen and therefore classified as a Group A by the US Environmental Protection Agency (EPA) [44]. It is toxic for cardiovascular, liver, organ development, and immune systems, genotoxic, and harmful to aquatic life [21]. Yet, in 2017, the Agency for Toxic Substances and Disease Registry (ATSDR) ranked VCM fourth on the Substance Priority List, after arsenic, lead and mercury [45]. This is a biannually updated list of substances which are common in industry and determined to pose the most significant threat to human health [45].

The effect of exposure to VCM differs for acute and chronic exposure. Acute exposure to VCM has been linked to effects on the central nervous system, respiratory tract, cardiovascular and gastrointestinal systems, as well as causing damage to eyes and teeth $[44,45]$. At lower levels acute exposure causes dizziness, and at higher concentrations it can lead to a loss of consciousness [45], or death via respiratory depression [45]. Chronic exposure to VCM has been shown to affect a 
number of biological systems in humans and animals. Various studies in humans have found links between VCM exposure and altered microcirculation [46], raynauds disease, hypertension, thrombocyopenia (decreased platelets, which effects blood clotting), splenomegaly (enlarged spleen), hepatic (liver) damage and abnormalities, impaired sexual performance, preeclampsia in pregnant women, acroosteolysis (the dissolution of bones), scleroderma-like skin damages (thickening of the skin), effects on the immunological system and increased lymphocytes, effects on the central nervous system (tingling, numbness and pain in the extremities), neuropsychiatric symptoms [45], chromosomal damage, mutagenicity and formation of DNA adducts [44]. Chronic exposure to VCM has also been shown to cause cancer. Multiple studies have shown a causal relationship between VCM and hepatic cancers [45]. Studies have also found statistically significant increases in mortality from cancers of the brain, central nervous system, lung and respiratory system, connective and soft tissues, and lymphatic/hematopoietic system. These results have not been consistently repeated in other studies [42,45].

\section{History of Recognition of Issues with VCM and Setting of Exposure Limits in PVC Manufacture}

In 1930, two early studies of health impact of the key components of the PVC manufacture (ethylene dichloride and VCM) were undertaken at the request of the Carbide and Carbon Chemical Corporation, one of the early leaders in manufacture of ethylene-based chemicals [47], and the US Bureau of Mines $[48,49]$. The studies were undertaken at the Pittsburgh Experiment Station of the US Bureau of Mines and focused on assessing acute toxicity from single exposure on guinea pigs. For both ethylene dichloride and VCM, congestion and edema of the lungs was reported as the main site of toxic response, with kidney lesions noted as a secondary damage site. Both chemicals lead to deaths of testing animals when exposed to high doses, which can be seen as clearly demonstrating their toxicity. However, their harmfulness was reported in relative terms emphasizing that there was no observed damage at lower levels of exposure and by comparing these to other chemicals. VCM was reported as 'less harmful than carbon tetrachloride and chloroform' and therefore the researchers concluded that ' $[\mathrm{t}]$ he narcotic action of VCM and its comparatively low toxicity suggest its possible use for surgical anesthesia' [49]. The use of VCM as anesthetic was subsequently researched [50]. Findings for ethylene dichloride concluded with comparisons that 'for single exposures and periods of an hour or more the toxicity of ethylene dichloride appears to be of about the same order as gasoline, benzene, carbon tetrachloride, and chloroform' [48]. The studies also observed because of a clear odor at lower concentrations, ethylene dichloride exposure can easily be observed and therefore eliminated [48], which was much harder for VCM because it 'does not possess adequate warning properties of the odor or irritation type' [49].

Unfortunately, these early animal studies had a number of limitations. They exclusively focused on acute toxicity for single exposure, which prevented any observations on chronic exposure and carcinogenesis, consequently underreported the totality of impacts. However, these studies appear to have been reflective of the state of the science at the time, given that the subsequent work one of the key researchers, Frank Arthur Patty, served to set the standard for modern industrial hygiene and toxicity [51]. These 1930 studies signal that before the development of extensive manufacture of PVC, at least acute toxicity of its main ingredients was recognized, and therefore the manufacture of PVC was developed after there was already sufficient information to suspect that this industry could present health problems. In the decades that followed, the production process was improved, controlling better against releases of VCM.

The carcinogenicity of VCM was formally recognized in 1974. It was a case report of an extremely rare form of liver cancer, angiosarcoma of the liver, in three PVC resin workers that provided sufficient evidence of a causal relationship with VCM exposure and the development of cancer [52]. Two studies in particular have contributed to the epidemiological evidence for the carcinogenicity of VCM [52]. Both were large, multi-center cohort studies, looking at exposure to VCM in production plants, one 
in the US and one in Europe. The majority of subjects worked in PVC or VCM production plants. These studies provided convincing evidence that VCM causes both angiosarcoma of the liver and hepatocellular carcinoma. Both studies reported a 'substantial excess' of angiosarcoma of the liver. In the European study, and a sub-cohort in Italy, the risk for hepatocellular carcinoma increased substantially with the duration of employment and cumulative exposure to VCM. The US based study did not have diagnostic information about hepatocellular carcinoma. In many studies, the lack of 'definitive' clinical information makes it difficult to distinguish between hepatocellular carcinoma and angiosarcoma of the liver and other secondary neoplasms (abnormal tissue growth). However, an increased risk of liver cirrhosis, which is a risk factor for hepatocellular carcinoma, as a result of exposure has been observed in other studies [52]. This was not confirmed by either the US or European cohorts [53]. The risk for both angiosarcoma of the liver and hepatocellular carcinoma increased for higher cumulative exposure. However, the actual incidence of angiosarcoma of the liver and hepatocellular carcinoma for workers employed after 1975 is lower than those employed before this time, with an increased latency period for the development of cancer in those employed after 1975 [45,53]. The link between liver cancer and VCM is now well established, with these results being witnessed in other studies, and further confirmed by the follow-up studies of these original cohorts [53-56].

Following the recognition of its carcinogenicity, many countries put regulations in place to limit exposure to VCM. During the mid-1970s the exposure standards in most countries were set at approximately $5-10 \mathrm{ppm}\left(13-26 \mathrm{mg} / \mathrm{m}^{3}\right)$. Improvements within the industry resulted in immediate drops in exposure to VCM. The improvement of PVC resin production and the PVC polymerization process both led to reductions in exposure to VCM. [52]. Prior to 1974 estimates from the chemical industry indicated that exposure to VCM was several thousands of milligrams per cubic meter in the 1940 and 1950s, and several hundreds of milligrams per cubic meter in the 1960s and early 1970s [52]. However, even after the implementation of exposure standards high levels of VCM have been reported in many countries [42]. Additionally, some countries allow for much higher levels of exposure than others. The Occupational Safety and Health Administration (OSHA) permissible exposure limit is $1 \mathrm{ppm}$, or approximately $2.56 \mathrm{mg} / \mathrm{m}^{3}$, for the 8-h working day over a normal working lifetime [57]. This is also called a Threshold Limit Value-Time Weighted Average (TLV-TWA). Most countries have an exposure limit of $3 \mathrm{ppm}\left(7.77 \mathrm{mg} / \mathrm{m}^{3}\right)$ or less. However, China has a limit of $10 \mathrm{mg} / \mathrm{m}^{3}$, and New Zealand, Australia and Singapore have some of the highest permissible levels of $5 \mathrm{ppm}$ $\left(13 \mathrm{mg} / \mathrm{m}^{3}\right)$ [58]. The exposure limit of $1 \mathrm{ppm}$, recommended by ACGIH, has been calculated to minimize the potential for liver cancer [58]. This does not necessarily prevent other forms of damage to biological systems that VCM is likely to cause.

The concentration of VCM is generally monitored by environmental measures. This is not able to measure individual intoxication levels, which are impacted by the numerous factors of individual responses to exposure. Biological monitoring, which measures biomarkers associated with VCM exposure, is able to reflect the actual degree of VCM intoxication [59].

\section{Developing Scholarship on VCM Exposure and PVC Manufacture}

Despite the existing regulations for VCM exposure, medical understanding of the processes involved is still developing. For example, recent research using biomarkers to measure individual exposure to VCM is indicating that cellular damage from VCM occurs at concentrations below the generally recommended levels, and is influenced by common genetic polymorphisms [60].

Data from animals and humans indicates that VCM is absorbed efficiently and rapidly by inhalation and dermal exposure [21,44]. Following inhalation, VCM is primarily metabolized in the liver to the electrophilic intermediates, chloroethylene oxide and chloroacetaldehyde [60]. These compounds are both able to bind to proteins, DNA and RNA and may also form DNA adducts [52]. Exposure to VCM has been shown to lead to chromosomal damage [61-63], specific point mutations and altered mRNA expression of genes involved in cell processes [60,64], and markedly 
altered lipid and amino acid metabolites which may increase the risk of disease [65]. Studies of workers exposed to VCM and patients with existing angiosarcoma of the liver or pre-malignant angiosarcoma lesions identified the presence of specific point mutations in serum. The increased presence of these genes was also associated with cumulative exposure to VCM [60].

However, this varied between individuals, indicating a potential relationship between gene polymorphisms controlling the activation/ detoxification of VCM and DNA repair [60]. The extent of DNA damage is able to be measured by the amount of micronuclei (MN) detected (MN frequency). The human cell is made up of an outer membrane, a nucleus containing genetic material and a gel-like cytoplasm between the two. Chromosomes are made up of tightly coiled DNA and are situated within the nucleus of the cell. Micronuclei are small breaks from chromosomes or whole chromosomes that did segregate into two daughter cells during mitosis [61]. Micronuclei are induced by defects in cell repair processes, the accumulation of DNA damages and chromosomal aberrations, and various genotoxic agents which may lead to 'cell death, genomic instability, or cancer development' [66].

A recent review found an increase in MN frequency in exposed compared to non-exposed subjects, in their meta-analysis of six studies [60]. This same review, used the findings in these studies to recommend a benchmark dose level (BMDL). A few the studies included in the review estimated a benchmark dose (BMD) for the increase in micronuclei due to VCM exposure. This threshold corresponded with the 95th-percentile of the MN frequencies within the control groups. Any increase in MN frequency beyond this threshold would indicate possible VCM induced chromosomal damage. Bolognesi et al., used this threshold to calculate a new permissible exposure limit/TLV-TWA of $0.5 \mathrm{mg} / \mathrm{m}^{3}$, for the protection of worker health [60].

These recent studies suggest that new insights are still possibly going to change the current understanding of the VCM exposure. It has already been shown that for some well-recognised risks, such as lead and asbestos, medical understanding of the biological responses continued long after the initial bans of use of these substances [67]. More sophisticated understanding of the cellular processes, genetic and hormonal changes tend to complement older knowledge which has already established acute toxicity responses.

\section{PVC Additives}

The issues with PVC do not end with the toxic core components, but rather, the manufacture of PVC products use a number of additives, to improve the performance of the material. The most common additives are heat stabilizers, fillers, pigments, gliders and plasticizers [68]. These improve heat performance, the appearance of the product and, if needed, add flexibility. Heat stabilizers and gliding agents stop thermal decomposition during processing and molding [3]. PVC would thermally decompose into VCM. When exposed to heat VCM releases corrosive hydrochloric acid and phosgene $\left(\mathrm{COCl}_{2}\right.$ or $\left.\mathrm{CCl}_{2} \mathrm{O}\right)$ fumes [21]. Phosgene can be spontaneously generated when exposed to as little energy as sunlight from chlorine and carbon monoxide, which is why it has been associated with natural ageing, or heating of many organochlorines. Although, VCM is considered to be fully reacted in PVC products and therefore not released from these, PVC without heat stabilizers can be fragile on this level.

Historically, common stabilizers included heavy metals, such as cadmium, lead, tin and zinc. Toxic heavy metals cadmium and lead have only recently been removed from PVC stabilizers. The deadline for voluntary removal of lead stabilizer from PVC in the EU was as recent as 2015, preceded in 2005 by the voluntary removal of lead in PVC piping for water supply [23], and 2001 voluntary phasing out of cadmium [3]. In 2017, however, the website of the European Council of Vinyl Manufacturers (ECVM) was still reporting on the long history, excellent properties, and cost-effectiveness of lead as a stabilizer of PVC [23]. Other common stabilizers include organotin (compounds of tin and hydrocarbons), calcium-zinc, and barium/zinc [23]. Organic based stabilizers (OBS) and 1,3-dimetyl-6-aminouracil (DAU) are the new replacement stabilizers, and outperform the older stabilizers in terms of heat resistance and increased recyclability [69]. Unfortunately, 
these replacement substances have not been thoroughly tested for their impact on human health. Detailed definitions of OBS are difficult to find, and DAU has only been used more intensely recently [21]. The impacts of stabilizers should therefore be included in assessments of the total health risks posed by various polymers and their recycling.

The quantity of additives required depends heavily on the final product. In uPVC, additives total into less than $10 \%$ by weight [68]. However, in PPVC, plasticizers are also added to increase their flexibility and transparency, and are used in proportions as varied as $10-60 \%$ of the final PVC products [70]. There is a range of substances that can be used as plasticizers including phthalates, aliphatics, epoxy, terephthalates, trimellitates, polymerics, and phosphates [43]. However, because plasticizers are not part of the chain of polymers that make plastics, they can be slowly released from these products [70]. The largest consumer of all plasticizers is $\mathrm{PPVC}$, which makes up $80-90 \%$ of global consumption [43]. Phthalates are one of common plasticizers. These are aromatic chemicals containing a phenyl ring with two attached and extended acetate groups [45].

Since 2008, the ECHA has included eight phthalates in their list of substances of very high concern [22]. This is a list of substances which under their REACH program require authorization before use and currently contains 43 substances-phthalates make one fifth of the total list. Phthalates are also produced in fairly high volume of over 235,000 tons per year [71], with PPVC as their main consumer. The following phthalates are listed as substances of very high concern: bis(2-ethylhexyl)phthalate (DEHP) in 2008, dibutyl phthalate (DBP) in 2008, benzyl butyl phthalate (BBP) in 2008, diisobutyl phthalate (DIBP) in 2009, bis(2-methoxyethyl) phthalate in 2011, n-pentyl-isopentylphthalate in 2012, diisoentylphthalate (DIPP) in 2012, and diethyl phthalate (DPP) in 2013. The reason for including these chemicals is their toxicity for reproduction, with more specific reasons ranging from impairing fertility, causing harm to the unborn child, and being an endocrine disruptor [22]. Some have also been noted as dangerous for the environment and toxic for aquatic organisms. The majority of these phthalates are colorless or lightly colored liquids, which have little or no smell, making it practically very difficult to observe any exposure to phthalates, especially when these are released from finished plastic products. Based on such assessments, use of phthalates in toys that can be put into a baby's mouth has been regulated against in the Europe since 1999 [72] and in 2015, the EU Commission adopted a ban on four phthalates most recognized as being a problem; this will come into force in 2019 for most electrical applications [73].

There is still limited epidemiological evidence related to phthalates, and decisions to classify these chemicals as being of very high concern are mainly based on animal studies. DEHP is the most researched and understood phthalate to date. Studies of its health impact on rats have established that it is an endocrine disruptor with antiandrogenic activity, and it suppresses testosterone-related processes [74]. Once DEHP is absorbed by the lining of the gut, it metabolizes into mono-2-ethylhexyl phthalate (MEHP), which has androgenic activity ten times greater than that of DEHP [74]. Early animal studies have so far tended not to quantify the impact of lower doses and more complex combinations of factors on human health. However, when biomonitoring of concentrations of phthalate metabolites was undertaken in the general population using blood and urine, the blood results suggested that over $75 \%$ of the US population is exposed to phthalates, while for urine this was as high as $95 \%$ [75].

\section{End of Life for PVC}

\subsection{Recycling of $P V C$}

Although PVC is a thermoplastic, and therefore potentially well-suited for recycling, the totality of added stabilizers, plasticizers and any other substances during its manufacture all play a role in the recyclability of the material at the end of its life. The possibility of release of toxic fumes during PVC recycling and health concerns with some of the historical additives create potentially compelling disadvantages. However, much used PVC is potentially available for recycling, with one recent estimate reporting that the size of current PVC in-use stock is as high as $270 \mathrm{~kg} /$ capita [68]. 
In recent years there has been a significant increase in recycling of PVC in the EU, where between the early 2000s and 2016 the volume of recycled PVC increased at least 22 times [76], while still remaining under $1 \%$ globally. Germany and the UK are responsible for about half of the European recycling, while PVC profiles present almost half of recycled PVC, followed by pPVC (non-electric), rigid pipes, fittings, and films, and electrical cables [76].

Corresponding to this increase, there has been a rise in discussion of possible toxicity implications of such recycling. In 2015, the EU Parliament recommended that the European Commission should not authorize the recycling of plastics which contain the phthalate DHEP, saying '[r]ecycling should not justify the perpetuation of the use of hazardous legacy substances' [77]. What is important to observe is that discussions of this kind tend to focus on the most obvious issues. DHEP is not the only problem additive commonly found in PVC available for recycling, although it was the only issue signaled in this discussion. As previous section explained a number of additives to PVC present serious health risks.

The other very significant problem with recycling of PVC is that, as explained, the VCM has chemical potential to break when heated and that all chlorine containing materials when combusted incompletely leads to the formation of dioxins. It is known that many house, backyard, and landfill fires lead to the release of dioxins from PVC [3], and there is significant speculation that the thermal fragility of VCM could allow for similar releases during recycling. This is an area where greater scientific clarity is still needed. Nevertheless, the suspicion is real making it relevant to observe that this issue is not even regularly mentioned in sources discussing PVC recycling. This failure to consider already known issues associated with recycling of PVC suggests a continuation of the pattern of poor recognition of the importance of human health.

\subsection{Disposal of PVC}

For a material to be truly sustainable, it should have minimal adverse impacts during the disposal stage. This is especially important for PVC, because as the previous section shows, it is not a good candidate for recycling. Similarly, like the majority of other petrochemicals, PVC could theoretically be used as a fuel or incinerated (although uPVC does require another fuel for this). However, as already explained, any heating of VCM can lead to release of dioxins, it has already been established that burning of PVC in many house, backyard and landfill fires leads to the release of dioxins. Some work has reported that under controlled combustion conditions at high enough temperature, some of the dioxin formation could be mitigated [3]. Unfortunately, the same work did not report on what happens to the PVC additives during this combustion, leaving it open to speculate that stabilizers, such as possibly cadmium and lead, or plasticizers could potentially be released during this process.

The biodegradation of common polymers has been receiving more attention in recent years. It is generally considered that it takes place in two steps: (1) fragmentation of the polymers into fragments, followed by the (2) bioassimilation of the polymer fragments by microorganisms [78]. However, both of these processes are slow, and greatly depend on the chemical structure of the polymer and the environmental conditions [78]. In 2000, the European Commission reviewed landfilling of PVC and established that it shows very modest degradation even after decades in landfills [79]. However, they also reported that the additives were released, with heavy metal stabilizers presenting greater problems due to their biopersistency than phthalate plasticizers which chemically reacted with other surrounding material [79].

One area of development in recent years has been understanding which microorganism might be able to accelerate the biodegradation of certain polymers. At the moment, many of the promising findings require specialized species and conditions for this [80]. Some have suggested that the white rot fungi might be able to biodegrade PVC [81].

While this might prove to be the start of a very relevant development, current practices for disposal of PVC present much more real issues. It has been recognized that accidental fires of general landfills continue to be likely, and they might contain unknown amounts of PVC [79]. PVC and other plastics stored for recycling present another fire risk. In 1991, in Thetford, UK, over a $72 \mathrm{~h}$ period a fire 
consumed about 1000 metric tons of plastic which was sitting on a plastic waste site and contained PVC, PE, polypropylene (PP), ABS and polystyrene (PS) [82]. The medical team called in to estimate the health impact this might pose for the local community and concluded that it was difficult to fully describe and quantify the exposure [82]. While accidents of this kind are never desired, the issue with using plastics is that such risks are an inherent feature of these materials.

The absence of known safe ways of disposing of used PVC, and recognition of the likely problems associated with burning and release of additives, lead to a conclusion that disposal should be recognized as one of the undesirable aspects of PVC.

\section{Construction Applications of PVC}

Because the construction industry is the single most significant user of PVC, this is also where the greatest improvements can be made. PVC currently dominates some niches of the construction market. In the US and Canada, more than $70 \%$ of newly installed buried water distribution pipes are made of PVC, and $75 \%$ of sewer piping [83]. Service life for these uses are not fully understood and tend to be estimated as anywhere between $40-80$ years [84]. Generally, affordability is seen as the main advantage of PVC. However, for all construction applications of PVC alternatives already exist in the market.

Of all other polymers, polyethylene (PE) can effectively replace many of the construction applications of PVC. Polyethylene comes in high-density (HDPE) and low-density forms (LDPE) and is currently considered to be one of the safer polymers in common use [13]. In recent years, high-density polyethylene (HDPE) has been increasingly used instead of other materials for larger public waters supply pipes and tanks. It is suitable for larger and smaller extrusions and currently it is already used for a range of tubes, pipes, plastic or wood-plastic timber, and also in flexible applications for electrical cables and damp-proof membranes [13,85]. Low-density polyethylene (LDPE) is also suitable for flexible applications such as damp-proof membranes [13,85]. Any use of either HDPE and LDPE instead of PVC reduces the complex health issues associated with PVC. In addition, because ethylene is normally used in manufacture of PVC (Figure 2), any decrease in use of PVC can increase the availability of, the far less harmful alternative, polyethylene (PE).

Poly(acrylonitrile-co-butadiene-co-styrene) (ABS) is another solid polymer which is already used in pipes and plumbing fixtures and faces of electric sockets [85]; however, toxic components are also needed for its manufacture [13], which makes it hardly an advantageous upgrade. A number of other plastics can be used for damp-proofing [13]. Many of these present lesser health risks.

Importantly, there are also good non-plastic alternatives to PVC. Alternatives for UPVC piping include metal pipes (copper, galvanized iron, etc.) for smaller fittings and vitrified clay and concrete for larger in ground applications [86]. PVC gutters and downpipes have also become ubiquitous, despite a well-known predecessor in galvanized iron and other metal alternatives [87]. Use of uPVC for windows has already shown great limitations for any repair once damaged, leaving again the predecessor, timber windows, as better performing [87].

Non-plastic alternatives of pPVC are also readily available. The most significant application in this group has been vinyl flooring, which has its natural alternative in linoleum. Predating vinyl, linoleum was invented in 1860. It is a natural composite made by mixing oxidized linseed oil with tree resins, wood flour, cork, and limestone fillers, with added pigments [88]. However, rise in vinyl came at a great cost to the linoleum industry. By the mid-1980s only three manufacturers remained in the world [89]. While there has been an increase in interest in linoleum in recent years, more careful studies have observed that due to the continuing process of oxidation of linseed oil, some samples released high levels of VOCs even after the installation [88]. Such problems can be seen as indicative of the relative neglect of development of this product while its manufacture was stagnating. It seems reasonable to expect that they can be avoided with careful new product designs [13]. Other hard flooring materials are also readily available, such as tiles, wood, cork, and are often recognized as healthier alternatives [90]. Alternatives for other pPVC applications are available in unplasticized wallpapers and numerous coating systems which do not include PVC. 
Finally, it should be acknowledged that the construction industry is not the exclusive user of PVC, which is also common in packaging [2], but more importantly, PVC is still used in a number of disposable medical products [79]. Arguably, elimination of PVC from medical applications and food packaging should predate its elimination in construction. However, the sizes common in construction lead to proportionally very voluminous applications, requiring more of potentially toxic ingredients. Because the size is relevant here, this is where the construction industry could show some real leadership and help decrease the total use of toxic components of PVC.

An additional consideration when discussing PVC is that ever since the 1930 studies of the PVC components till today, the PVC industry played a significant role in development of knowledge in this area. The PVC industry sponsored the initial toxicology studies in 1930, but in recent years, many rebuttals of new scientific findings came from the researchers associated with the PVC industry. For example, in 2013, the Indoor Air journal presented in the same issue an original article on PVC and its rebuttal. Carlstedt et al. presented data showing that the use of plasticized PVC as flooring was associated with the increase in human uptake of phthalates in infants [91]. The rebuttal by the Blakey, Ott, Peters and Risotto, all authors at the time employed by the vinyl industry, challenged the results based on a small number of procedural imperfections, reflective of a research design which involved infants [92]. Quick rebuttals, such as this one presents a real challenge to development of knowledge which highlights issues with PVC, consequently providing a basis for continuation of problematic practices.

\section{Conclusions}

The information on PVC shows that there are significant health issues on a number of separate levels. The majority of key components used in the manufacture of PVC are well-recognized for their toxicity and this is an inherent feature of PVC. Despite efforts to limit the occupational exposures to these, new research is suggesting that additional decreases of the exposure levels are likely to be needed, at least for VCM. Although it is possible to aspire to improvement, because of the unavoidable use of chlorine and VCM, only reductions of exposure are possible, with elimination of the toxic components remaining impossible for PVC.

In addition to the toxic initial ingredients, PVC has historically received a high dose of additives which are also problematic in terms of their impact on human health. These could be designed out of future PVC products. However, any consideration of recycling of PVC has to actively factor in the heritage of such practices as a real problem.

Finally, to date, there is no certainty surrounding the eventual decomposition of disposed PVC. Currently, a number of more lasting plastics are still to arrive at the point in time when they naturally start decomposing, often hundreds of years after initial manufacture. PVC belongs to this group. What is already known is that additives are released before the polymer chain is broken. Therefore, grimmer surprises could still present themselves in this area.

This evaluation of PVC in relation to health shows that this material poses great risks on a number of levels during the production, while in use, and after use. This is especially important as the suitability of PVC for sustainable construction is evaluated against the SDGs. As Figures 1 and 2 showed, in the case of PVC, the health of users of the built environment is not the only concern, but also the impact manufacture of PVC could present on the life on land, life below water and generally the availability of clean water; just as the same manufacture should be part of efforts to develop responsible consumption and production, industry, innovation and infrastructure, reduce inequalities and support decent work and economic growth, jointly leading to climate action and partnership for the goals. While the importance of occupational exposure to toxic components has been recognized as relevant for many years now, when approached from the perspective of the SDGs, occupational exposures can be seen as directly related to social inequalities and poor employment opportunities. These problems should be seen as part of the intrinsic qualities of PVC, and every use of PVC as supporting such practices. Therefore, by using the lenses of SDGs it is possible to considerably expand 
upon the already existing approaches to the sustainability of building materials. In the case of PVC, this only emphasizes the importance of decreasing its use in construction.

Furthermore, all of the scientific work reviewed in this article points at the simple proposition that any and all use of PVC is problematic. While, pPVC did receive more bad press in recent years and, as explained, there are some real problems with the additives used in their manufacture, the same can be said for PVC itself. Therefore, issues with PVC can be summed up as being issues of how much it is used-the more of it, by volume, that is used, the more harm is imbedded in such use. This again places a great importance on the way construction industry uses or avoids this material.

While PVC currently is a common choice because it is cheap, there are straightforward alternatives to PVC in construction and there are compelling reasons to use these more. After all, buildings significantly predate the invention of plastics.

Acknowledgments: The study was supported by the Research Establishment Grant of the Victoria University of Wellington, New Zealand.

Author Contributions: Emina Kristina Petrović conceived the article, contributed most of the material and lead the writing of the article. Lydia K. Hamer has conducted the research on the manufacture-related issue and wrote the sections reporting on those findings.

Conflicts of Interest: The authors declare no conflict of interest.

\section{References}

1. Greenpeace. PVC-Free Future: A Review of Restrictions and PVC Free Policies Worldwide, 8th ed.; Greenpeace International: Amsterdam, The Netherlands, 2001. Available online: www.greenpeace.org (accessed on 15 September 2017).

2. Ceresana. Market Study: Polyvinyl Chloride-PVC. 2016. Available online: www.ceresana.com (accessed on 15 September 2017).

3. Zhang, M.; Buekens, A.; Jiang, X.; Li, X. Dioxins and polyvinylchloride in combustion and fires. Waste Manag. Res. 2015, 33, 630-643. [CrossRef] [PubMed]

4. HIS Chemical. Chemical Economic Handbook: IHS Chemical: Plasticizers. Available online: www.ihs.com (accessed on 14 September 2016).

5. Petrović, E.K.; Vale, B.; Wilson, M.S. Vinyl and linoleum flooring: Health issues as perceived by lay people and architects. J. Green Build. 2016, 11, 159-177. [CrossRef]

6. United Nations Sustainable Development Goals. Available online: http:/ /www.un.org/sustainabledevelopment/ (accessed on 6 December 2017).

7. Schultz, P.W.; Nolan, J.M.; Cialdini, R.B.; Goldstein, N.J.; Griskevicius, V. The constructive, destructive, and reconstructive power of social norms. Psychol. Sci. 2007, 18, 429-434. [CrossRef] [PubMed]

8. Milfont, T.L. Global warming, climate change and human psychology. In Psychological Approaches to Sustainability: Current Trends in Theory, Research and Applications; Verdugo, V.C., Armenta, M.F., Cadena, C.H., Eds.; Nova Science Publishers Inc.: New York, NY, USA, 2010.

9. Dobbie, M.F.; Farrelly, M.A.; Brown, R.R. Mechanisms for Unpacking Socio-Institutional Pathways for Change: A Research Compendium from A4.1; Cooperative Research Centre for Water Sensitive Cities Ltd.: Melbourne, Australia, 2017.

10. Brown, R.R.; Farrelly, M.A.; Loorcach, D.A. Actors working the institutions in sustainability transitions: The case study of Melbourne's stormwater management. Glob. Environ. Chang. 2013, 23, 701-718. [CrossRef]

11. Binetti, R.; Costamanga, F.M.; Marcello, I. Exponential growth of new chemicals and evolution of information relevant to risk control. Ann.-Ist. Super Sanità 2008, 44, 13-15. [PubMed]

12. American Chemical Society (CAS). Available online: www.cas.org (accessed on 16 August 2017).

13. Petrović, E.K. An overview of health hazards from materials: Application of principles. In Materials for a Healthy, Ecological and Sustainable Built Environment: Principles for Evaluation; Petrović, E.K., Vale, B., Zari, M.P., Eds.; Woodhead Publishing: Cambridge, UK, 2017; pp. 203-236, ISBN 978-0-08-100707-5.

14. Rass-Hansen, J.; Falsig, H.; Jørgensen, B.; Christensen, C.H. Perspective bioethanol: Fuel or feedstock? J. Chem. Technol. Biotechnol. 2007, 82, 329-333. [CrossRef] 
15. Vogt, E.T.C.; Weckhuysen, B.M. Fluid catalytic cracking: Recent developments on the grand old lade of zeolite catalysis. Chem. Soc. Rev. 2015, 44, 7342-7370. [CrossRef] [PubMed]

16. White, W.C. Butadiene production process overview. Chem.-Biol. Interact. 2007, 166, 10-14. [CrossRef] [PubMed]

17. Christensen, C.H.; Rass-Hansen, J.; Madsen, C.C.; Taarning, E.; Egeblad, K. The renewable chemicals industry. ChemSusChem 2008, 1, 283-289. [CrossRef] [PubMed]

18. Carson, R. Silent Spring; Houghton Mifflin Company: Boston, MA, USA, 1962.

19. Allanou, R.; Hansen, B.G.; van der Bilt, Y. Public Availability of Data on EU High Production Volume Chemicals, Released in 1999. Available online: http://www.chemicalspolicy.net/downloads/ DataAvailabilityEUHPV.pdf (accessed on 16 August 2017).

20. Akovali, G. Plastic materials: Polyvinyl chloride (PVC). In Toxicity of Building Materials; Pacheco-Torgal, F., Jalali, S., Fucic, A., Eds.; Woodhead Publishing: Cambridge, UK, 2012; pp. 23-53.

21. PubChem Compound-Review of Chemicals by the National Center for Biotechnology Information (NCBI). Available online: www.ncbi.nlm.nih.gov (accessed on 6 December 2017).

22. European Chemicals Agency (ECHA). Chemicals Search from European Chemicals Agency (ECHA). Available online: www.echa.europa.eu (accessed on 6 December 2017).

23. The European Council of Vinyl Manufacturer (ECVM). Available online: www.pvc.org (accessed on 6 December 2017).

24. CIEC (Centre for Industry Education Collaboration), 2016. Available online: http:/ / www.essentialchemicalindustry. org/chemicals/chlorine.html (accessed on 15 September 2017).

25. Lakshmanan, S.; Murugesan, T. The chlor-alkali process: Work in progress. Clean Technol. Environ. Policy 2014, 16, 225-234. [CrossRef]

26. Lin, Y.; Wang, S.; Wu, Q.; Larssen, T. Material Flow for the Intentional Use of Mercury in China. Environ. Sci. Technol. 2016, 50, 2337-2344. [CrossRef] [PubMed]

27. O'Brien, T.F.; Bommaraju, T.V.; Hine, F. Chlor-Alkali Technologies. In Handbook of Chlor-Alkali Technology: Volume I: Fundamentals; Springer: Boston, MA, USA, 2005; Volume 1, pp. 387-442, ISBN 978-0-306-48623-4.

28. European Commission. Reach Restrictions. 2017. Available online: https://ec.europa.eu/growth/sectors/ chemicals/reach/restrictions_en (accessed on 22 December 2017).

29. EPA (Environmental Protection Association). Preliminary Information on Manufacturing, Processing, Distribution, Use, and Disposal: Asbestos; Office of Chemical Safety and Pollution Prevention, U.S. Environmental Protection Agency: Washington, DC, USA, 2017; pp. 1-15.

30. Hua, P.; Vasyukova, E.; Uhl, W. A variable reaction rate model for chlorine decay in drinking water due to the reaction with dissolved organic matter. Water Res. 2015, 75, 109-122. [CrossRef] [PubMed]

31. Bond, T.; Huang, J.; Graham, N.J.D.; Templeton, M.R. Examining the interrelationship between DOC, bromide and chlorine does on DBP formation in drinking water-A case study. Sci. Total Environ. 2014, 470, 469-479. [CrossRef] [PubMed]

32. Stockholm Convention. Available online: www.pops.int (accessed on 6 December 2017).

33. World Health Organization (WHO). Dioxins and Their Effects on Human Health-Fact Sheet, Updated October 2016. Available online: http: / / www.who.int (accessed on 15 September 2017).

34. Akovali, G. Plastic materials: Chlorinated polyethylene (CPE), chlorinated polyvinylchloride (CPVC), chlorosulfonated polyethylene (CSPE) and polychloroprene rubber (CR). In Toxicity of Building Materials; Pacheco-Torgal, F., Jalali, S., Fucic, A., Eds.; Woodhead Publishing: Cambridge, UK, 2012; pp. 54-75.

35. VinylPlus. 'The PVC Production Process Explained' Online Video Clip. Vimeo, 2015. Available online: https: / /vimeo.com/145974516 (accessed on 11 September 2017).

36. Muddada, N.B. The Influence of Dopants on Copper Chloride Catalysts for Ethylene Oxychlorination Reaction. Ph.D. Thesis, University of Oslo, Oslo, Norway, November 2012.

37. Scharfe, M.; Lira-Parada, P.; Paunović, V.; Moser, M.; Amrute, A.P.; Pérez-Ramírez, J. Oxychlorination-Dehydrochlorination Chemistry on Bifunctional Ceria Catalysts for Intensified Vinyl Chloride Production. Angew. Chem. Int. Ed. 2016, 55, 3068-3072. [CrossRef] [PubMed]

38. Akovali, G. Plastics Rubber and Health; Smithers Rapra Technology Ltd.: Shawbury, UK, 2007; p. 79, ISBN 184735081X, 9781847350817.

39. Lakshmanan, A.; Biegler, L.T. A case study for reactor network synthesis: The vinyl chloride process. Comput. Chem. Eng. 1997, 21, S785-S790. [CrossRef] 
40. Benyahia, F. The VCM Process Economics: Global and Raw Materials Impacts. In Proceedings of the 1st Annual Gas Processing Symposium, Doha, Qatar, 10-12 January 2009; Alfadala, H., Reklaitis, G.V., El-Halwagi, M.M., Eds.; Elsevier: Amsterdam, The Netherlands, 2009; p. 416.

41. Burgess, R. Manufacture and Processing of PVC; Applied Science Publishers: London, UK, 1982; p. 23.

42. International Agency for Research on Cancer (IARC); Vinyl Chloride. IARC Monographs: Chemical Agents and Related Occupations; IARC Working Group on the Evaluation of Carcinogenic Risks to Humans; International Agency for Research on Cancer: Lyon, France, 2008; Volume 97, pp. 311-444, ISBN 9789283212973.

43. IHS Market. Available online: www.ihs.com (accessed on 6 December 2017).

44. EPA (Environmental Protection Agency). Toxicological Review of Vinyl Chloride; U.S. Environmental Protection Agency: Washington, DC, USA, 2000; pp. 1-197.

45. ATSDR (Agency for Toxic Substances and Disease Registry). Available online: www.atsdr.cdc.gov (accessed on 6 December 2017).

46. Lopez, V.; Chamoux, A.; Tempier, M.; Thiel, H.; Ughetto, S.; Trousselard, M.; Naughton, G.; Dutheil, F. The long-term effects of occupational exposure to vinyl chloride monomer on microcirculation: A cross-sectional study 15 years after retirement. BMJ Open 2013, 3, e002785. [CrossRef] [PubMed]

47. Union Carbide Corporation-History. Available online: www.unioncarbide.com (accessed on 6 December 2017).

48. Sayers, R.R.; Yant, W.P.; Waite, C.P.; Patty, F.A. Acute response of guinea pigs to vapors of some new commercial organic compounds: I. ethylene dichloride. Public Health Rep. 1930, 45, 225-239. [CrossRef]

49. Patty, F.A.; Yant, W.P.; Waite, C.P. Acute response of guinea pigs to vapors of some new commercial organic compounds: V. vinyl chloride. Public Health Rep. 1930, 45, 1963-1971. [CrossRef]

50. Oster, R.H.; Carr, C.J. Anesthesia; narcosis with vinyl chloride. Anesthesiology 1947, 8, 359-361. [CrossRef] [PubMed]

51. Patty, F.A. Industrial Hygiene and Toxicology; Interscience Pr: New York, NY, USA, 1949.

52. International Agency for Research on Cancer (IARC); Vinyl Chloride. IARC Monographs: Chemical Agents and Related Occupations; IARC Working Group on the Evaluation of Carcinogenic Risks to Humans; International Agency for Research on Cancer: Lyon, France, 2012; Volume 100F, pp. 451-478, ISBN 9789283213239.

53. Mundt, K.A.; Dell, L.D.; Crawford, L.; Gallagher, A.E. Quantitative estimated exposure to vinyl chloride and risk of angiosarcoma of the liver and hepatocellular cancer in the US industry-wide vinyl chloride cohort: Mortality update through 2013. Occup. Environ. Med. 2017, 74, 709-716. [CrossRef] [PubMed]

54. Wong, R.H.; Chen, P.C.; Du, C.L.; Wang, J.D.; Cheng, T.J. An increased standardised mortality ratio for liver cancer among polyvinyl chloride workers in Taiwan. Occup. Environ. Med. 2002, 59, 405-409. [CrossRef] [PubMed]

55. Hsieh, H.I.; Chen, P.C.; Wong, R.H.; Du, C.L.; Chang, Y.Y.; Wang, J.D.; Cheng, T.J. Mortality from liver cancer and leukaemia among polyvinyl chloride workers in Taiwan: An updated study. Occup. Environ. Med. 2011, 68, 120-125. [CrossRef] [PubMed]

56. Ward, E.; Boffetta, P.; Andersen, A.; Colin, D.; Comba, P.; Deddens, J.A.; De Santis, M.; Engholm, G.; Hagmar, L.; Langard, S.; et al. Update of the Follow-Up of Mortality and Cancer Incidence among European Workers Employed in the Vinyl Chloride Industry. Epidemiology 2001, 12, 710-718. [CrossRef] [PubMed]

57. NIOSH (National Institute for Occupational Safety and Health), Vinyl Chloride, Centers for Disease Control and Prevention. 2016. Available online: https://www.cdc.gov/niosh/npg/npgd0658.html (accessed on 18 December 2017).

58. Work Safe New Zealand. Workplace Exposure Standard (WES) Review: Vinyl Chloride; Work Safe New Zealand: Wellington, New Zealand, 2017.

59. Hao, J.N.; Xu, X.Y.; Lian, X.; Zhang, C.; Yan, B. A luminescent 3d-4f-4d MOF nanoprobe as a diagnosis platform for human occupational exposure to vinyl chloride carcinogen. Inorg. Chem. 2017, 56, 11176-11183. [CrossRef] [PubMed]

60. Bolognesi, C.; Bruzzone, M.; Ceppi, M.; Kirsch-Volders, M. The lymphocyte cytokinesis block micronucleus test in human populations occupationally exposed to vinyl chloride: A systematic review and meta-analysis. Mutat. Res. 2017, 774, 1-11. [CrossRef] [PubMed]

61. Wang, Q.; Tan, H.S.; Zhang, F.; Sun, Y.; Feng, N.N.; Zhou, L.F.; Ye, Y.J.; Zhu, Y.L.; Li, Y.L.; Brandt-Rauf, P.W.; et al. Polymorphisms in BER and NER pathway genes: Effects on micronucleus frequencies among vinyl chloride-exposed workers in Northern China. Mutat. Res. 2013, 754, 7-14. [CrossRef] [PubMed] 
62. Kumar, A.K.; Balachandar, V.; Arun, M.; Ahamed, S.A.; Kumar, S.S.; Balamuralikrishnan, B.; Sankar, K.; Sasikala, K. A comprehensive analysis of plausible genotoxic covariates among workers of a polyvinyl chloride plant exposed to vinyl chloride monomer. Arch. Environ. Contam. Toxicol. 2013, 64, $652-658$. [CrossRef] [PubMed]

63. Jiao, J.; Feng, N.N.; Li, Y.; Sun, Y.; Yao, W.; Wang, W.; Zhang, G.H.; Sun, S.Y.; Tan, H.S.; Wang, Q.; et al. Estimation of a safe level for occupational exposure to vinyl chloride using a benchmark dose method in central China. J. Occup. Health 2012, 54, 263-270. [CrossRef] [PubMed]

64. Qiu, Y.L.; Sun, P.; Wang, W.; Wang, T.; Xia, Z.L. Messenger RNA expression and genetic polymorphisms of cell cycle control genes and chromosomal aberrations in Chinese vinyl chloride monomer-exposed workers. J. Occup. Environ Med. 2011, 53, 1442-1446. [CrossRef] [PubMed]

65. Guardiola, J.J.; Beier, J.I.; Falkner, K.C.; Wheeler, B.; McClain, C.J.; Cave, M. Occupational exposures at a polyvinyl chloride production facility are associated with significant changes to the plasma metabolome. Toxicol. Appl. Pharmacol. 2016, 313, 47-56. [CrossRef] [PubMed]

66. Luzhna, L.; Kathiria, P.; Kovalchuk, O. Micronuclei in genotoxicity assessment: From genetics to epigenetics and beyond. Front. Genet. 2013, 4, 131. [CrossRef] [PubMed]

67. Petrović, E.K. Persisting issues with the most recognized building materials health risks: Lead and asbestos. In Materials for a Healthy, Ecological and Sustainable Built Environment: Principles for Evaluation; Petrović, E.K., Vale, B., Zari, M.P., Eds.; Woodhead Publishing: Cambridge, UK, 2017; pp. 155-174, ISBN 978-0-08-100707-5.

68. Ciacci, L.; Passarini, F.; Vassura, I. The European PVC cycle: In-use stock and flows. Resour. Conserv. Recycl. 2017, 123, 108-116. [CrossRef]

69. Asawakosinchai, A.; Jubslip, C.; Rimdusit, S. Organic based heat stabilizers for PVC: A safer and more environmentally friendly alternatives. Key Eng. Mater. 2015, 659, 321-326. [CrossRef]

70. Liu, Z.; Little, J.C. Semivolatile organic compounds (SVOCs): Phthalates and flame retardants. In Toxicity of Building Materials; Pacheco-Torgal, F., Jalali, S., Fucic, A., Eds.; Woodhead Publishing: Cambridge, UK, 2012; pp. 122-137.

71. Environmental Protection Agency (US)_EPA. Available online: www.epa.gov (accessed on 7 August 2013).

72. European Commission. Permanent Ban of Phthalates: Commission Hails Long-Term Safety for Children's Toys; European Commission: Brussels, Belgium, 2005. Available online: http:/ / europa.eu/rapid/press-release_ IP-05-838_en.htm (accessed on 15 September 2017).

73. EUR-Lex. Commission Delegated Directives (EU) 2015/683. Official Journal of the European Union, 4 June 2015. Available online: http:/ / eur-lex.europa.eu/legal-content/EN/TXT/?uri=uriserv:OJ.L_.2015.137.01.0010. 01.ENG\#ntr1-L_2015137EN.01001001-E0001 (accessed on 15 September 2017).

74. Martinez-Arguelles, D.B.; McIntosh, M.; Rohlicek, C.V.; Culty, M.; Zirkin, B.R.; Papadopoulos, V. Maternal in utero exposure to the endocrine disruptor di-(2-ethylhexyl) phthalate affects the blood pressure of adult male offspring. Toxicol. Appl. Pharmacol. 2013, 266, 95-100. [CrossRef] [PubMed]

75. Xu, Y.; Liu, Z.; Park, J.; Clausen, P.A.; Benning, J.L.; Little, J.C. Measuring and predicting the emission rate of phthalate plasticizer from vinyl flooring in a specially-designed chamber. Environ. Sci. Technol. 2012, 46, 12534-12541. [CrossRef] [PubMed]

76. Vinyl Plus. Recycling. Available online: https://vinylplus.eu/progress/22/68/Recycling (accessed on 15 September 2017).

77. News European Parliament. Don't Allow Recycling of Plastics That Contain Toxic Phthalate DEHP, Wars MEPs; Press Release 25 November 2015. Available online: http:/ / www.europarl.europa.eu/news/en/pressroom/20151120IPR03616/don-t-allow-recycling-of-plastics-that-contain-toxic-phthalate-dehp-warnmeps (accessed on 15 September 2017).

78. Vroman, I.; Tighzert, L. Biodegradable polymers. Materials 2009, 2, 307-344. [CrossRef]

79. European Commission DGXI.E.3. The Behaviour of PVC in Landfill; A Report by the European Commission; European Commission: Brussels, Belgium, 2000.

80. Álvarez-Berragán, J.; Domíniguez-Malfavón, L.; Vargas-Suárez, M.; González-Hernández, R.; Aguilar-Osorio, G.; Loza-Tavera, H. Biodegradable activities of selected environmental fungi on a polyester polyurethane varnish and polyether polyurethane foams. Appl. Environ. Microbiol. 2016, 82, 5225-5235. [CrossRef] [PubMed]

81. Klrbas, Z.; Keskin, N.; Güner, A. Biodegradation of polyvinylchloride (PVC) by white rot fungi. Bull. Environ. Contam. Toxicol. 1999, 63, 335-342. 
82. Baxter, P.J.; Heap, B.J.; Rowland, M.G.M.; Murray, V.S.G. Thetford plastic fire, October 1991: The role of a preventative medical team in chemical incidents. Occup. Environ. Med. 1995, 52, 694-698. [CrossRef] [PubMed]

83. Vinyl Institute. Uses. Available online: http:/ / www.vinylinfo.org (accessed on 17 January 2018).

84. European Commission. Life Cycle Assessment of PVC and of Principal Competing Materials; A Report by the European Commission; European Commission: Brussels, Belgium, 2004.

85. Ceresana. Various Pages. Available online: www.ceresana.com (accessed on 7 December 2016).

86. Mother Earth Living. Available online: https://www.motherearthliving.com/home-products/nh-builderscorner (accessed on 26 January 2018).

87. Greenpeace. Available online: http://www.greenpeace.org/international/en/campaigns/detox/polyvinylchloride/pvc-free-solutions / (accessed on 17 January 2018).

88. Lent, T.; Silas, J.; Vallette, J.; Healthy Building Network. Resilient Flooring and Chemical Hazards: A Comparative Analysis of Vinyl and Other Alternatives for Health Care: Report for Health Care Research Collaboration. 2009. Available online: http://www.healthybuilding.net/docs/HBN-ResilientFlooring\& ChemicalHazards-Report.pdf (accessed on 15 June 2014).

89. BBC. Scotland's Landscape: Kirkcaldy (Fife). Available online: http://www.bbc.co.uk/scotland/landscapes / kirkcaldy/ (accessed on 15 June 2014).

90. Petrović, E. Building Materials and Health: A Study of Perceptions of the Healthiness of Building and Furnishing Materials in Homes. Ph.D. Thesis, Victoria University of Wellington, Wellington, New Zealand, 2014. Available online: http:/ /hdl.handle.net/10063/3187 (accessed on 17 January 2018).

91. Carlstedt, F.; Jönsson, B.A.G.; Bornehag, C.G. PVC flooring is related to human uptake of phthalates in infants. Indoor Air 2013, 23, 32-39. [CrossRef] [PubMed]

92. Blakey, A.; Ott, K.; Peters, T.; Risotto, S. Letter to the editor: Anti-PVC advocacy disguised as science. Indoor Air 2013, 23, 85-86. [CrossRef] [PubMed]

(C) 2018 by the authors. Licensee MDPI, Basel, Switzerland. This article is an open access article distributed under the terms and conditions of the Creative Commons Attribution (CC BY) license (http:/ / creativecommons.org/licenses/by/4.0/). 